\title{
A busca por relações de alteridade como manifestação do sagrado no espaço urbano do centro da cidade de São Paulo
}

\section{The quest for alterity as manifestation of the sacred at São Paulo city centre}

Fernando de Oliveira Amorim*

\begin{abstract}
Resumo: A prática concreta da arquitetura e urbanismo representa expressões físicas de uma cultura através das experiências humanas no tempo e no espaço. Refletir sobre a "arquitetura dos espaços sagrados" convida à compreensão do sagrado manifestando-se no espaço urbano, pois, a partir da dimensão simbólica que a arquitetura e urbanismo representam, todo lugar possui significados, valores e sentimentos. Nesse espaço urbano pode-se observar a manifestaçâo do sagrado enquanto sinônimo de vida e alteridade no centro histórico da cidade de São Paulo, considerado marco zero na formação da urbe.
\end{abstract}

Palavras-chave: Espaço urbano. Sagrado selvagem. Direito à cidade. Alteridade.

Abstract: The concrete practice of architecture and urbanism represents physical expressions of a culture through human experiences at time and space. Reflecting about the "architecture of sacred spaces" invites the understanding of the sacred manifesting in urban space, because from the symbolic dimension that architecture and urbanism represent every place has meanings, values and feelings. In this urban space, it's able to observe the manifestation of the sacred as a synonym of life and otherness in the historical center of the city of Sáo Paulo, considered a landmark in the formation of the city.

Keywords: Urban space. Sacred wild. Right to the city. Otherness.

\section{Introdução}

Refletir sobre a relação entre arquitetura e espaços sagrados é um convite a refletir sobre as manifestaçóes cotidianas das pessoas como prática significante e expressóes físicas no tempo e no espaço arquitetônico. Busca-se compreender o sagrado enquanto manifestação de alteridade a partir da dimensão simbólica da arquitetura, pois todo lugar arquitetônico possui significados, valores e sentimentos a partir do relacionamento das pessoas entre si e com o espaço ao redor. Como argumenta Yi-Fu Tuan, geógrafo sino-americano, essa relação é topofilia, um elo afetivo entre a pessoa e o ambiente físico; difuso como conceito, mas vívido e concreto como experiência pessoal (TUAN, 1980). Nesse espaço difuso, mas vívido, pode-se observar a manifestação do sagrado enquanto sinônimo de vida da "alma coletiva" (a própria sociedade), expressa na sociologia de Émile Durkheim. Sagrado como sede de uma potência da alteridade, por sua vez

* Doutor em Arquitetura e Urbanismo (USP). Contato: filosofia.arqurb@gmail.com. 
compreendida não como negação da identidade ou como oposição do eu e do não eu, mas como possibilidade de um espaço de autonomia na relação com o outro diferente.

Mircea Eliade, filósofo e cientista das religiôes, em sua obra "O Sagrado e o Profano", observa que a experiência primeira do espaço sagrado constitui um alicerce sobre o qual é possível desenvolver a arquitetura urbana, domiciliar e religiosa. Exorta para o fato de que a experiência da habitação humana é precedida pela experiência do lugar santo provisório, pois as experiências cotidianas concernentes aos templos, cidades e casas derivam da experiência primária de um espaço sagrado. A experiência do sagrado vai além da experiência da crença em Deus, em deuses ou em seres imateriais, pois é para o ser humano a consciência de sua existência no mundo; um mundo de interdiçóes e realidades compartilhadas num espaço que não é homogêneo, mas qualitativamente diferenciado e distinto (ELIADE, 2001).

Promovendo um diálogo entre a Psicologia e a Ciências da Religião, o psicólogo Ênio Brito (1996) argumenta que a manifestação do sagrado no espaço representa um processo humano, social e cultural a partir da coletividade do criar e recriar representaçóes e práticas. Nessa coletividade, as pessoas constroem suas concepções sobre o mundo e sobre si. Nesse sentido, a experiência do sagrado estrutura relaçóes objetivas entre os seres humanos (a partir da experiência com o outro), bem como relaçóes com o mundo e o cotidiano (a partir da experiência com o espaço arquitetônico).

Nesse contexto, observa-se as considerações do sociólogo francês Roger Bastide sobre o conceito de "sagrado selvagem". Este seria uma revolta contra o instituído social (o sagrado instituído/domesticado) na condição necessária de criar um social in statu nascendi, tendo o "selvagem" como o "antidomesticado", pois por definição um sagrado selvagem é criação pura (imaginação) e não repetição. A manifestação desse sagrado selvagem é a "pura experimentação de uma alteridade que permanecerá confusa e difusa, ato gratuito, ou simples gestos de revolta" (BASTIDE, 2006, p. 154). Alteridade num espaço de arquiteturas que se transformam cotidianamente a partir das relaçóes das pessoas consigo mesmas e com o ambiente ao redor, a partir das esferas políticas, ideológicas, culturais e socioeconômicas.

Considerando o exposto, o objetivo deste artigo é refletir sobre a manifestação do sagrado no espaço urbano, mais precisamente na área do Centro tradicional paulistano, considerado marco zero na formação da cidade. Sua simbologia e heterogeneidade representam útero fecundo capaz de gestar, nutrir e dar forma às relaçóes sociais no espaço urbano a partir do relacionamento com o outro prefigurando o processo de alteridade.

\section{O centro histórico: novos usos, novos usuários}

No período entre as décadas de 1970 a 2000, as mudanças na configuração socioeconômica internacional e nacional impactam diretamente a estrutura das cidades brasileiras ao intensificar um processo de substituição das antigas áreas centrais por novos polos de atração econômica. Conforme pesquisas do arquiteto urbanista Eduardo Nobre, neste estágio de investimentos e produção do capital equipamentos urbanos como casas de espetáculos, centros de convençôes, hotéis e shopping centers surgem 
em antigos terrenos industriais e/ou várzeas drenadas e aterradas às margens do Rio Pinheiros, na regiáo sudoeste da capital paulista. Contam com investimentos públicos em anéis viários e dinamização de sistemas de transporte coletivo, valorizando uma área que apresenta valorizaçáo de aproximadamente 4.000\% desde a década de 1970 (NOBRE, 2000). Nesse cenário, por não mais atrair os interesses do capital imobiliário, os centros consolidados váo lentamente sendo esquecidos e até mesmo abandonados pelo poder público. Para o também arquiteto urbanista Flávio Villaça (2001), a “expansão legal” urbana nas últimas três décadas é determinada pelo capital imobiliário. Ao deslocar-se para o quadrante sudoeste do município mantém outras áreas da cidade como áreas em pousio social (aguardando valorização imobiliária), como por exemplo, o "Centro tradicional", com seus prédios abandonados propositalmente enquanto expressão simbólica e hierárquica das diferenças de classes.

Por Centro tradicional ou áreas centrais tradicionais compreende-se o ponto de convergência de trajetos, encontro, descanso e abastecimento definindo-o, numa perspectiva histórica, como lugar de trocas comerciais e de atividades religiosas, de lazer, política, cultural, financeira e de comando. Essa definição articula o Centro enquanto espacialização hierárquica das atividades humanas com a cidade a partir de sua função e significados, presentes na diversidade étnica e social constituída a partir de processos históricos (muitas vezes conflituosos e contraditórios). Para as arquitetas urbanistas Heliana Vargas e Ana Luisa Castilho, com a expansão (espontânea ou planejada) das demais áreas urbanas ocorre um processo de enfraquecimento da noção de Centro tradicional, que passa a sofrer concorrência com uma rede de subcentros. Esse processo contribui para a degradação de centros urbanos na Europa e América do Norte desde a década de 1950 e, no Brasil, a partir da década de 1980 (VARGAS e CASTILHO, 2006) ${ }^{1}$.

Em São Paulo, esses projetos de requalificação nos eixos de expansão urbana na região sudoeste buscam obter e potencializar ganhos fundiários a partir de diferenças locacionais associados a determinado prestígio social da vizinhança, com consequente valorização imobiliária. Contrariamente, o Centro tradicional, antiga moradia da elite cafeeira, vai adquirindo status de território popular com imóveis privados e espaços públicos em condiçóes de abandono e precários. Para o sociólogo Heitor Frúgoli Jr., especialista em Antropologia Urbana, o "velho centro" passa então a ser caracterizado como um problema social (FRÚGOLI JR., 2000). Este "velho centro" se configura a partir do chamado "triângulo histórico" formado pela ocupação (física e simbólica) da Ordem de São Bento (com o Mosteiro de São Bento, a Basílica e o Colégio), Ordem Terceira de São Francisco (com o Convento e a atual Faculdade de Direito da USP) e a Ordem Terceira do Carmo (com o antigo Convento e a atual Capela). E, envolto por esse triângulo histórico, há a presença da Companhia de Jesus (com o Pátio do Colégio, local da fundação da cidade), conforme pode ser observado na Figura $1^{2}$.

1 As autoras dividem os processos de intervenção urbana em áreas centrais em três períodos: Renovação Urbana (décadas de 1950 e 1960); Preservação Urbana (décadas de 1970 e 1980) e Reinvenção Urbana (década de 1990 até os dias atuais).

2 Importante ressaltar que a menção às quatros ordens religiosas cristãs católicas tem como objetivo realizar uma descrição histórica, pois em conjunto com a Coroa Portuguesa foram entidades responsáveis pela ocupação e defesa do território. 
Atravessada pelo caminho entre o triângulo histórico e o rio Tietê, a regiáo da Luz e Santa Ifigênia, caminho utilizado por tropeiros e saídas de bandeiras, adormecida e considerada um arrabalde, recebe em 1799 o Jardim Público chamado de Horto Botânico (posteriormente Parque da Luz). Na gestão de João Theodoro Xavier de Matos (1872-1875), então presidente da Província de São Paulo, são criadas condições de comunicação entre os charcos da Luz e o Centro histórico da cidade com as estaçóes ferroviárias Luz (São Paulo Railway) e Júlio Prestes (Estrada de Ferro Sorocabana). Visando atender uma crescente demanda da elite cafeeira, surge o primeiro empreendimento imobiliário ao norte do triângulo histórico: a Chácara do Capão Redondo (atual Campos Elíseos), marcada por novos palacetes, arruamentos e bondes.

\section{Figura 1 - Triângulo histórico na fundação da cidade de Sáo Paulo}

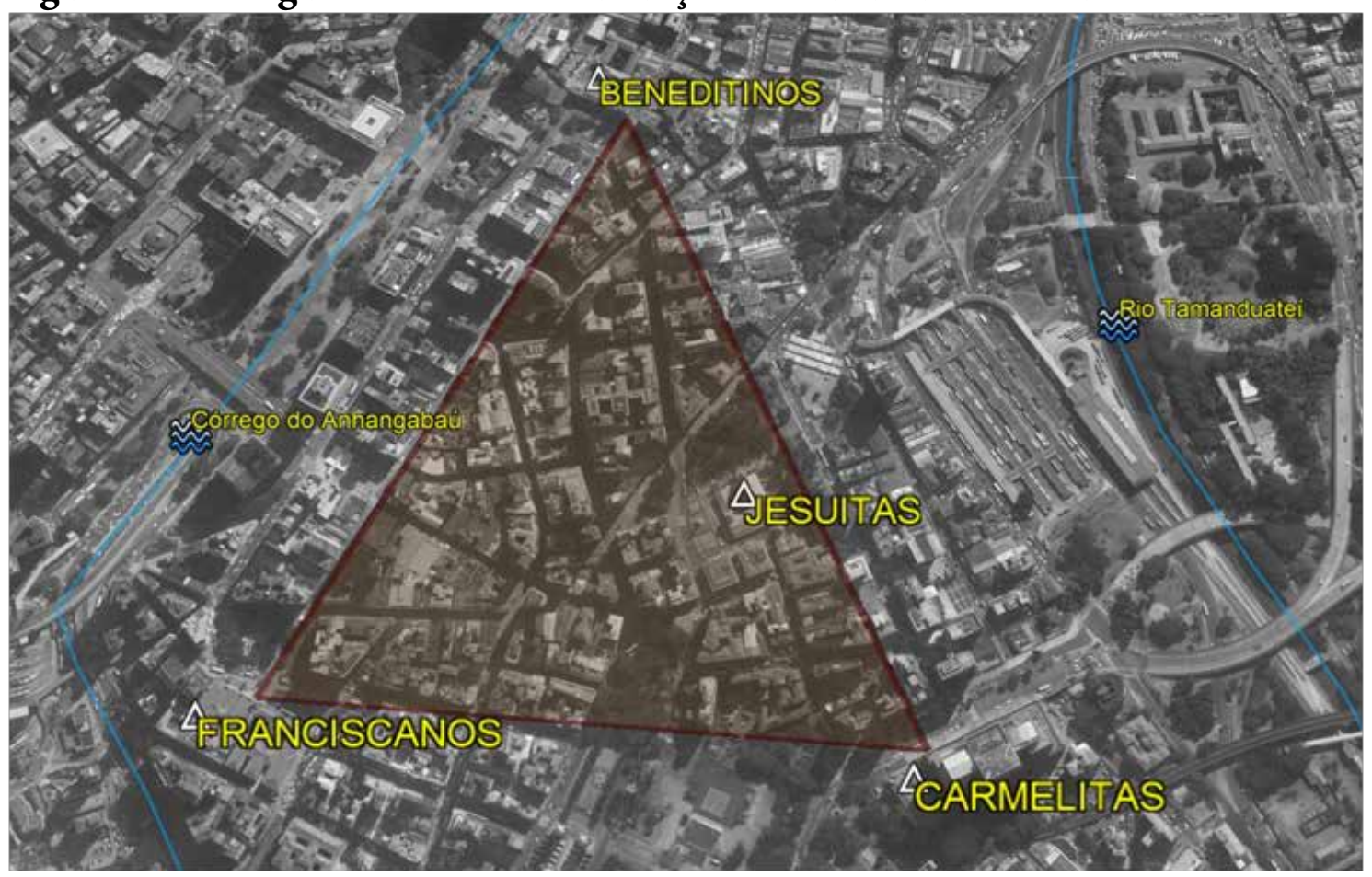

Fonte: Google Earth, 2018. Organização do autor. Sem escala.

No final do século XIX, a região do Parque da Luz passa por intervenções arquitetônicas e urbanísticas que marcam a paisagem: Quartel da Força Pública (1892), Escola Politécnica (1894), Escola Prudente de Moraes (1895), Liceu de Artes e Ofícios, inconcluso e posteriormente ocupado pela Pinacoteca do Estado. Entre 1899 e 1910, na gestão do prefeito Antônio Prado, o Parque da Luz (agora Jardim da Luz), recebe novo paisagismo com árvores exóticas, coretos e passeios, sendo desfrutado pela elite moradora do entorno que vivencia este espaço com exclusividade. Segundo o arquiteto urbanista Simóes Junior (2004), paralelamente, entre os anos de 1887 e 1900, período marcado pela Lei Áurea (1888) e Proclamação da República (1989), desenvolve-se em Sáo Paulo um aglomerado de insalubres cortiços reunindo libertos, pobres e o novo operariado.

A proximidade das duas realidades (palacetes e cortiços), acompanhada pela preocupação em melhorar as condições de habitação na região da Luz e Santa Ifigênia, 
conduz a uma intervenção pública ao promover infraestrutura de drenagem e saneamento. Para o arquiteto urbanista Nabil Bonduki, a escolha dessa área não é casual. Naquele momento histórico, outros bairros na capital também apresentam condiçóes semelhantes de insalubridade, com problemas sanitários e foco de epidemias das mais diversas, mas é na região dos Campos Elísios que se observa uma intervenção completa. Observa-se que a partir da década de 1920-1930 o gradativo aumento da facilidade de locomoção (promovida pelo automóvel) desencadeia um processo de valorizaçáo de terrenos e proliferação de bairros para parcela da população com maior poder de consumo de bens e serviços. Essas pessoas, aos poucos, vão abandonando os bairros mais próximos à ferrovia como Campos Elíseos, Luz e Santa Ifigênia. Concomitantemente, ocorre uma expansão (muitas vezes sem controle e sem ordenamento) de assentamentos precários nas áreas alagadiças, principalmente em direção à região Leste (BONDUKI, 1998). Ressalta-se que a presença da ferrovia na área central passa a representar um limite à expansão de bairros residenciais para esta elite econômica redirecionando-a ao quadrante sudoeste (VILLAÇA, 2001).

No decorrer da década de 1930, Prestes Maia e Ulhôa Cintra elaboram o Plano de Avenidas (estrutura viária radio-concêntrica numa combinação do modelo de sistema de radiais e perimetrais). Esse plano vai estruturar o crescimento da cidade nas décadas seguintes. Nos anos de 1940, na administração Prestes Maia, com a intenção de tirar os usos indesejados dos arredores da Praça da República, as atividades de meretrício até então próximas da Rua Timbiras são transferidas para a Rua Itaboca (atual Professor Cesare Lombroso) nas proximidades do Jardim da Luz, unindo-se às casas noturnas e prostíbulos existentes. Situação que vai permanecer até os anos 1980, com a ocupação definitiva das ruas do bairro pelo comércio de vestuários e afins a partir da Rua José Paulino. Com a crescente industrialização substituindo o ciclo econômico do café, a região central recebe edifícios e grandes avenidas, e passa a desempenhar um papel estrutural para uma mobilidade baseada principalmente no automóvel.

Na década de 1950, a proximidade com a dinâmica de passageiros da Estação da Luz, a gradativa degradação das edificaçóes que já não são mais ocupadas pelas camadas com maior poder de consumo (capazes de sua manutenção), o congelamento dos aluguéis e a consequente atração de casas de meretrício transformam a região. A mudança de uso vai transformando a área central que, de local de residência, começa a receber comércio e serviços. Essas camadas com maior poder de consumo passam a ocupar as áreas vizinhas ao Centro e as camadas menos favorecidas economicamente ou continuam nos cortiços ou vão para favelas e subúrbios. Os deslocamentos dessas camadas economicamente favorecidas configuram as sucessivas transferências de centralidades em direção ao sudoeste: do Centro tradicional à Avenida Paulista e, posteriormente, para a Avenida Luis Carlos Berrini (FRUGOLI JR., 2000). A partir da década de 1960 verifica-se na área central determinada deterioração econômica, física e social que corresponde à ideia de ineficiência funcional. Assim, por não atender as expectativas definidas pelo mercado imobiliário, passa a aguardar intervençóes públicas renovadoras. Portanto, pode-se afirmar que a regiáo central tradicional se reproduz de acordo com a dinâmica do crescimento urbano, mas este processo de reprodução e/ou readequação não é contínuo, pois está vinculado às demandas do mercado imobiliário (SIMÓES JR., 1994). 
No decorrer da década de 1970, apesar dos discursos e intençóes presentes nos planos urbanos, acentua-se o contraste entre a realidade de bairros ocupados por uma parcela de maior renda no eixo sudoeste e a realidade de áreas mais periféricas com problemas estruturais de moradia, transporte e infraestrutura básica (distribuição de água e coleta de esgoto), num claro contexto de espoliação urbana de trabalhadores com menor renda e menor poder de consumo. Essa espoliação urbana explicita uma forma de "mais valia" que, nas palavras do sociólogo e cientista político Lucio Kowarick (1979), atua sobre os destituídos de acesso a estes bens de consumo coletivos, necessários para garantir a sobrevivência cotidiana. E vai além, pois acentua práticas cotidianas alternativas de sobrevivência como a autoconstrução de moradias, por exemplo.

Na década de 1970, o Plano Diretor de Desenvolvimento Integrado (PDDI) cria duas autarquias para atender as necessidades da cidade relacionadas à habitação, circulação, trabalho e lazer: a Empresa Metropolitana de Urbanização (EMURB) em 1971, e a Coordenadoria Geral de Planejamento (COGEP), em 1972. O PDDI lança ainda a Lei Geral de Zoneamento (Lei Ordinária No 7.805/1972), que institui a figura das "Zonas Especiais" (Z8-200) como zonas de preservação de áreas com concentração de bens significativos como parques, áreas institucionais, conjuntos de valor histórico, etc. Nesse contexto é definida a maior Zona Especial da área central: "Área da Luz", conforme pesquisas da arquiteta urbanista Beatriz Kara-José (2007).

No entanto, desde as décadas de 1960-70 o que se observa são intervençôes públicas na área central relacionadas basicamente à circulação viária, com predomínio de investimentos em transporte individual como, por exemplo, a construçáo de viadutos que, circundando o Centro, oferecem uma ligação Leste-Oeste da cidade e transformam a área central em um nó articulador da acessibilidade metropolitana. Consequentemente, a condição degradante da área central se acentua, apresentando congestionamentos de trânsito, crescimento da poluiçáo do ar, ruídos, etc. Com o cruzamento das duas primeiras linhas de metrô (Azul Norte-Sul e Vermelha Leste-Oeste) e o ponto final das linhas radiais de ônibus (Praça da Bandeira, Praça Pedro Lessa, Parque Dom Pedro, Praça Princesa Isabel), a regiáo central passa a oferecer grande acessibilidade para o transporte público (FRUGOLI JR., 2000). Apesar da significativa infraestrutura e acessibilidade, desde a década de 1970 a área central passa a apresentar queda no crescimento populacional. De acordo com o "Boletim Informes Urbanos" No 2, de outubro de 2011, da Prefeitura Municipal de Sáo Paulo, a partir da década de 1980 observa-se uma queda na população absoluta marcando uma tendência demográfica no conjunto do Centro expandido e ampliando-se até uma faixa limítrofe nas zonas leste, norte e sul. Cenário que se mantém até meados da década de $2000^{3}$.

Com a crise internacional da década de 1980 e as posiçóes neoliberais de 1990, a economia nacional enfrenta momentos de crise com aumento do desemprego e crescimento

3 Os distritos que mais perdem população entre 1991 e 2000 passam a apresentar crescimento positivo na década de 2010: Pari (-3,95\% a.a., no período 1991-2000, para 1,56\% a.a., entre 2000- 2010), Bom Retiro (de $-3,35 \%$ a.a. para $2,45 \%$ a.a.), Sé (de $-3,29 \%$ a.a. para $1,63 \%$ a.a.) e Brás (de $-3,14 \%$ a.a. para $1,52 \%$ a.a.). O Boletim destaca ainda uma diminuição da evasáo populacional. Vale ressaltar que, ao observar a escala intra-urbana, verifica-se uma significativa presença de novos imigrantes no crescimento populacional de alguns distritos centrais, como Bom Retiro e Pari, por exemplo. 
da pobreza urbana, perceptível nas ruas e praças através da crescente presença de sem tetos, menores abandonados, prostitutas, mendicantes, etc. $\mathrm{O}$ comércio presente na região da Luz e Santa Ifigênia torna-se cada vez mais popular, pois busca tirar proveito do alto fluxo de pessoas que por ali circulam diariamente das periferias da cidade entre trens suburbanos e terminais de ônibus. Esse estado de abandono e degradação reforça a ocupação e permanência por uma população de menor poder aquisitivo, possível de ser observada no aumento de cortiços (adensados e insalubres) instalados em edifícios e casas antigas. Observa-se que a partir da subdivisão do imóvel em vários quartos (e sua locação), o cortiço (embora ilegal) representa atividade lucrativa para seus proprietários/ intermediários, com rendimentos maiores do que os obtidos com alugueis formais para uso residencial ou comercial, o que acaba por reforçar sua proliferação.

Com o abandono das camadas de maior poder aquisitivo, com a degradação do patrimônio histórico-artístico e com a reocupação pela camada de menor poder de consumo estabelece-se um cenário com novas potencialidades e dinamismos; passa-se a observar o crescimento de uma rede de hotelaria e restaurantes de padráo popular, comércio atacadista, indústria de confecçôes no Bom Retiro e Brás, comércio de máquinas e ferramentas na Rua Florêncio de Abreu e, o mais emblemático, a solidificação do comércio popular da Rua 25 de Março e adjacências. Esse dinamismo se traduz em milhares de pessoas circulando diariamente pela área central, refletindo no número de negócios e empregos, eventos culturais, mobilizaçóes, etc. A Rua Santa Ifigênia, reduto do "comércio" de produtos eletrônicos, passa a representar um dos maiores postos de arrecadação de ICMS do município, com valores bem acima de áreas em que se concentram shoppings centers de luxo (KOWARICK, 2007).

Em discursos oficiais presentes em parte da mídia impressa e televisiva, influenciando por sua vez a percepção de parte da sociedade, o processo de mudanças de usos na área central não é reconhecido como reocupação e/ou reprodução da vida local. Mas, acentua-se a percepção ideológica de que a população de menor poder aquisitivo, juntamente com a presença do morador de rua, simbolizam decadência nas proximidades da Luz e Santa Ifigênia. Consequentemente, obtido um consenso público da decadência, vende-se a ideia da necessidade de transformação da área a partir de grandes intervenções de embelezamento.

Entre fins da década de 1990 e início de 2000 ocorrem iniciativas como a "Operação Urbana Centro" no perímetro expandido da "Operação Urbana Anhangabaú”. Através de parcerias público-privadas, nos moldes do planejamento estratégico urbano, adota-se modelos de revitalização implantados em países de capitalismo central, sem levar em consideração que, nestes países, o acesso a serviços básicos (educação e saúde) e infraestrutura urbanas atendem amplamente a sociedade, não sendo uma especificidade da realidade brasileira. Para os arquitetos urbanistas Ermínia Maricato e João W. Ferreira, esses modelos de intervenção não surtem o efeito desejado ao não considerar a realidade desigual da sociedade brasileira, e ao tomar somente uma parte da cidade (a cidade do mercado) como o todo (MARICATO e FERREIRA, 2002).

Em 2004, na tentativa de articular as diferentes demandas de diferentes atores envolvidos no processo de produção e reprodução do espaço urbano central, inicia-se o Projeto "Reabilitação dos Bairros Centrais com Inclusão Social”. Com financiamento 
da Uniâo Europeia, esse projeto prevê a implantação de quatro Escritórios-Antenas nos bairros de Santa Cecília, Belém, Bom Retiro e Pari. O objetivo desses escritórios é fomentar capacitação profissional e, articulando-se com programas habitacionais, oferecer apoio a grupos em situação de vulnerabilidade social presentes na área central. Segundo pesquisas da assistente social Rosangela Pezoti (2012), em 2005 o projeto é reformulado e, sob a responsabilidade da Secretaria de Assistência e Desenvolvimento Social (SMADS), recebe o nome de "Nós do Centro". Passa a ter como objetivo promover a inclusão social das pessoas moradoras da área central buscando fomentar o aumento do nível de renda e consequentemente melhoria do padrão de vida.

Associado aos novos usos e novas ocupações da regiâo central, um caso chama atenção há pelo menos três décadas na área próxima à Luz e Santa Ifigênia, no polígono formado pelas avenidas Cásper Líbero, Ipiranga, Rio Branco, Duque de Caxias e Rua Mauá: um significativo crescimento da presença de usuários de drogas, marcando a regiáo pejorativamente como "Cracolândia", pela alta concentração de comércio e usuários de crack. Segundo Pezoti (2012), desde os anos 2000 açóes das Polícias Militar e Civil, ora isoladas, ora contando com o apoio da Prefeitura, buscam extinguir a presença desses usuários de crack. No início de 2005, iniciam-se atividades de "requalificar" a regiáo com limpeza urbana e policiamento focado na "Cracolândia". Em março de 2006, a "limpeza" da área se inicia com operaçóes força-tarefa para identificar irregularidades como falta de alvará de funcionamento, criminalidade, tráfico de drogas, prostituição, etc. Inicialmente, são realizadas quatro operações: Operação I (7 a 17 de março de 2005), Operação Luz (26 abril a 8 maio de 2005), Operação Campos Elíseos (18 a 27 de julho de 2005) e Operação Nova Luz (17 e 18 de novembro de 2005). Essas açôes se desenvolvem no decorrer das gestóes municipais, com uma última e desastrosa ação ocorrida em maio de 2017, quando a Prefeitura realiza uma ação com a Policia Militar sem levar em consideração as demais secretarias estaduais e municipais envolvidas no processo de coleta de informaçóes, reconhecimento, tratamento e acompanhamento dos usuários. Apesar de ser vendida como eficiente, a ação somente dispersa os dependentes químicos para outros pontos da cidade.

Concomitantemente, surgem propostas de intervençóes urbanas que se baseiam em obras de restauro e modernização de edifícios históricos da região da Luz e Santa Ifigênia, como a reforma da Pinacoteca do Estado, a construção da Sala São Paulo (na Estação Júlio Prestes) e o Museu da Língua Portuguesa (na Estação da Luz). Essas iniciativas são aprovadas nos circuitos culturais da cidade muitas vezes pautando-se no pretexto de resolver problemas de degradaçáo do entorno. Esses investimentos destinados às classes de médio e alto poder aquisitivo, aqueles que podem pagar por serviços e produtos como bares, restaurantes e vida noturna mais sofisticados, juntamente aos edifícios históricos e seus novos usos, passam a representar um papel de verdadeiras "iscas culturais". No entanto, para o arquiteto urbanista José Melo, a vivência noturna e sua circulação caracteristicamente boêmia exige outro qualificante: exige segurança e/ou até mesmo mais importante ainda, exige a "sensação" de segurança, pois seu contrário, a "sensação" de insegurança, afugenta o "público alvo" das "atividades âncoras" e/ou "iscas culturais" (MELO, 2014). 
Diante do exposto até o momento, pode-se afirmar que o enfraquecimento e a perda de funçóes conduzem esse Centro tradicional a um estado deteriorado (estragado, desmoronado) e degradado (aviltado, inferior, rebaixado). Segundo Vargas e Castilho (2006), a degradação vai além das estruturas físicas e influencia as açôes de grupos sociais, principalmente no que se refere à condição de empobrecimento, marginalizaçáo e destruição das bases da solidariedade e da noção de áreas públicas como bem comum. Abandono tanto por parte da população (responsável pelas relações nos espaços públicos - alteridade), quanto pelo poder público (responsável pelas obras públicas). Assim, a recuperação vai além da imagem física de seus edifícios. Deve objetivar, também, a manutenção e promoçáo de novas relaçôes de comunidade, do espírito de pertencimento ao lugar através da atração de investimentos, turismo, moradores e usuários que dinamizem a economia urbana e contribuam para a melhoria da qualidade de vida. E, nesse modelo de planejamento estratégico embasando um ideário de desenvolvimento urbano distintamente configurado para diferentes segmentos socioeconômicos, reafirma-se a noção de segregação e desigualdade socioespacial no território. Nesse sentido, ao refletir sobre o conceito de território enquanto espaço de poder, autonomia e desenvolvimento, o geógrafo Marcelo Souza (1995) instiga à busca pela resposta a uma questão central: como ocorre o processo de segregaçáo socioespacial? E, partindo desse questionamento, estabelece-se outras questóes: quem domina? Quem influencia?

\section{Planejamento estratégico e gentrificação}

Com a difusão do modelo de planejamento estratégico urbano pautado em intervençóes de cunho cultural em cidades ao redor do globo, observa-se que: 1) a instrumentalizaçáo da cultura no processo de reproduzi-la enquanto mercadoria, visando o desenvolvimento econômico; e 2) a não consideração da dinâmica local ao implantar os projetos (adotando projetos urbanísticos genéricos) conduzem à produçáo de espaços simulados e cidades como "parques temáticos", sem contextualização e significados para sua população local. Ressalta-se aqui que planejamento estratégico urbano e grandes intervenções urbanas pautadas sobre obras de arquitetos urbanistas famosos (e de apelo internacional), podem ser interpretados como eufemismo para gentrificação. Para a filósofa Otília Arantes, essas iniciativas vêm acompanhadas por uma "gentrificação estratégica" escamoteada por outros eufemismos como "revitalizaçáo, reabilitaçáo, revalorização, reciclagem, promoção, requalificação, até mesmo renascença, e por aí afora, mal encobrindo, pelo contrário, o sentido original de invasão e reconquista, inerente ao retorno das camadas afluentes ao coração das cidades" (ARANTES, 2000, p. 31).

Essa cultura de intervenção vendida como instrumento de requalificaçăo urbana não é capaz de representar as relaçóes sociais, de representar o "outro"; torna-se parte decisiva dos negócios, tornando-se, assim, ela mesma o grande negócio no contexto de um "pensamento único das cidades", como expóe Otília Arantes. A tirania de um pensamento único das cidades assimila a esfera cultural objetivando como resultado 
o chamado "planejamento cultural" . Este é marcado por obras e intervençôes que, concretamente, mais acentuam as desigualdades socioespaciais do que seu contrário: oferecer espaços de convivência e alteridade e, assim, diminuir tensões sociais urbanas. Esse tipo de planejamento, ao "otimizar" a imagem da cidade e vendê-la como locus atraente para investimentos, principalmente internacionais, incorpora a esfera da cultura e seus desdobramentos (o entretenimento, por exemplo), como potencialidades de renovação de áreas urbanas que passam por processos de mudanças de usos, muitas vezes consideradas como degradadas, a exemplo do Centro histórico paulistano.

Apresentada pelo planejamento estratégico como signo de competiçáo entre cidades, essa lógica de mercado encontra sua expressão mais desenvolvida em linguagens como "regeneraçáa" ou seu sinônimo "revitalizaçáo" urbana, e passa a ser o novo modus operandi das políticas públicas. Neil Smith, geógrafo escocês e estudioso do processo de gentrificação, alerta para o uso do termo "regeneração urbana" como uma vitória ideológica ao substituir deliberadamente a linguagem simples e honesta da gentrificação, termo atualmente considerado "grosseiro" para os promotores políticos e financistas, pois expõe a verdade sobre as reais mudanças sociais implicadas na "regeneração" das cidades. Para ele, "regeneração urbana" adquire um sentido de anestesiar as análises críticas sobre essas mudanças.

Os diversos projetos que buscam "regenerar" e/ou "revitalizar" as áreas urbanas dentro de uma estratégia urbana global podem provocar uma anomalia local compreendida a partir do termo "gentrificação". A gentrificação surge na combinação de poderes e práticas implementados com a intenção de "reconquistar" partes da cidade através de renovação urbana de dimensão classista. Essa gentrificação classista "conecta o mercado financeiro mundial com os promotores imobiliários (grandes e pequenos), com o comércio local, com agentes imobiliários e com lojas de marcas, todos estimulados pelos poderes locais" (SMITH, 2006, p. 79). O processo de gentrificação torna-se luta estratégica pelo território urbano reivindicado por numerosos grupos sociais, dentre os quais, recentemente, os de maior poder aquisitivo. Ao analisar criticamente as mudanças em curso, constata-se uma intenção em retomar o Centro através de atividades comerciais, de serviços, de lazer e, principalmente, culturais em projetos desenvolvidos pelo setor privado e pelo poder público, haja vista o exemplo da formulação do Projeto Nova Luz (arquivado por ser considerado inconstitucional ao náo respeitar diretrizes do Estatuto da Cidade - Lei Federal No 10.257/2001). A “regeneração" urbana na região da Luz e Santa Ifigênia, ao transformar os usos existentes, acaba eliminando setores de atividades que servem de sustento econômico para as camadas de menor poder de consumo, incapacitando-as de se manter nestas áreas centrais.

4 Termo expresso por Graeme Evans, professor de Cultura e Desenvolvimento Urbano na Maastricht University, Holanda, em sua obra "Cultural Planning: na urban renaissance?". O planejamento cultural constitui-se a partir de regras de arquitetura e urbanismo, dentre os quais o planejamento urbano incorporando arquitetos célebres, megaeventos, projetos e equipamentos culturais grandiosos para estabelecer uma imagem cultural atrativa a turistas e investidores externos, voltados principalmente ao mercado imobiliário. Exemplos: a filial em Bilbao/Espanha do Museu Guggenheim de Frank Gehry, a tentativa de implantar o Projeto Nova Luz na região da Luz e Santa Ifigênia e, mais recentemente, o Museu do Amanhã de Christian de Portzamparc no Rio de Janeiro. 
A partir da análise e interpretação dos inúmeros projetos e inciativas propostas para a área central, é possível afirmar que parte significativa destes projetos, mais do que requalificar a região, traz em si interesses econômicos ligados ao mercado imobiliário influenciando os rumos das políticas públicas. Entretanto, surgem alguns problemas. Mais do que promover o desenvolvimento da região central requalificando seus usos para atrair novos interessados sem descartar os existentes (bem como as pessoas que trabalham e moram na região), o objetivo é promover uma "revitalização" a partir da troca de usos e pessoas, pois ambos não atendem à demanda de mercado, ou seja, não apresentam condiçóes para consumir o novo produto (a nova mercadoria) a serem oferecidos com as intervençóes.

A crítica se baseia principalmente no processo de esvaziamento da cultura ao enfraquecer a participação crítica de seus envolvidos, pois, tratado como mercadoria e sujeita às leis do mercado (oferta e demanda), oferece ao público (consumidor) uma satisfação instantânea, que pode levar ao desencorajamento crítico, isto é, uma visão passiva e acrítica da sociedade em que se vive. No contexto no qual a cultura de massa vincula-se à manutenção de injustiças sociais, o planejamento estratégico urbano e cultural (que pode ser compreendido como um desdobramento da indústria cultural) evita a complexidade oferecendo produtos à interpretação literal. E, num estado de satisfação instantânea, não se desenvolve uma posição crítica perturbadora (catarse) frente ao status quo, já que seu consumo imediato náo conduz a uma atitude de compreendê-la. As cidades que buscam atrair investimentos na intenção de "se manter e se pagar", instauram uma lei de oferta e demanda transformando os espaços em mercadorias onde quem tem dinheiro usufrui, quem não tem é relegado a subespaços/espaços desumanos, condenando-se os mais pobres a se tornarem "reféns do espaço", como define o geógrafo Milton Santos (2008). Esses espaços não se tornam mera mercadoria, mas mercadoria de luxo destinada a potenciais compradores. E, ao considerar a cidade como uma mercadoria, desencadeia-se um processo de despolitização da cidade (de seus cidadãos), pois, de cidadãos, eles passam agora a consumidores.

Nesse contexto, ao desenvolver uma ontologia do espaço urbano a partir das relaçôes sociais, Milton Santos afirma que "onde não há o cidadão, há o consumidor mais-que-perfeito", pois o consumo tem sua própria força ideológica e material. Afirma que a condição de indivíduo urbano (habitante do espaço urbano) e, portanto, consumidor de bens materiais (ilusóes tornadas realidades como símbolos presentes em coisas que dão status) e também de bens imateriais ou culturais (associados a um consumo elitizado como turismo, viagens, clubes, etc.) não representa uma condição de cidadão. Nesse sentido, nem mesmo o eleitor (indivíduo político) pode ser conduzido forçosamente à condição de cidadão, "pois o eleitor pode existir sem que o indivíduo realize inteiramente suas potencialidades como participante ativo e dinâmico de uma comunidade" e seu papel de "eleitor não-cidadão" se esgota no momento do voto. Não é cidadão, pois se alimenta de "parcialidades, contenta-se com respostas setoriais, alcança satisfações limitadas, não tem direito ao debate sobre os objetivos de suas açóes, públicas ou privadas". Para ele, todo sistema que simplifica a realidade do mundo e a subordina à lógica dos negócios e noçôes de sucesso, transmite um "humanismo sem coragem”, sem visão sintética das coisas que existem. Um verdadeiro cidadão exercita 
eficazmente sua individualidade; desafia os mandamentos do mercado tornando-se, assim, um "consumidor imperfeito", pois é insubmisso a certas regras que, impostas pelo mercado, está fora dele mesmo (SANTOS, 2007, pp. 56-57).

Em contrapartida, pode-se compreender a cidade como útero fecundo no qual se gesta, nutre forma a vida social, psicológica e econômico-política. Por produzir e reproduzir açóes humanas, mais do que uma mera produção e reproduçáo de objetos, ela é obra de uma história de pessoas e de grupos. Como argumentava o filósofo Henri Lefebvre (1991, p. 111), "apenas grupos, classes ou fraçôes de classes sociais capazes de iniciativas revolucionárias podem se encarregar das, e levar até a sua plena realizaçáo, soluçôes para os problemas urbanos; com essas forças sociais e políticas, a cidade renovada se tornará a obra", À compreensão da produçáo de produtos no processo de domínio científico e técnico sobre a natureza material deve predominar o sentido da obra: apropriaçấo do tempo, espaço, corpo e desejo. Assim, a cidade é um caminho que se abre, o caminho da sociedade urbana e do humano como obra nessa sociedade que seria obra e não produto, formando assim o cidadáo. Cidadão que vivencia a cidade como obra inacabada, em um estado constante de transformaçóes e interaçóes (de subversóes), compreendendo a cidade como um útero fecundo de alteridade se (e somente se) estabelecer espaços de convivência entre os seres.

\section{Consideraçóes finais}

Mesmo contido numa estrutura social excludente, a pessoa constituinte da comunidade, na situação de sujeito, não é mera reprodutora de ideias, e utiliza sua capacidade imaginária ao assimilar e transformar significados atribuídos aos objetos reais para ideias manifestas. Apesar da situação de classe não determinar unicamente a história dessa pessoa, enquanto sujeito coletivo em seu grupo social ela desenvolve uma série de funçôes como produção, educação, gestão da coletividade e resolução dos litígios, ao estabelecer para si mesma novas maneiras de responder às suas necessidades.

Ao desenvolver essas funçóes em seu grupo social, elabora um conjunto de representações sociais vivenciado no espaço público e nos processos através dos quais desenvolve uma identidade, cria símbolos e se abre para a diversidade de um mundo de "outros". Nesse processo essa pessoa torna-se um ente social e não mais um ente passivo, mas um ente em constante interação e formulação de sua existência com as estruturas e ações sociais inscritas no espaço urbano, modificando este mesmo espaço e também a si mesma. Esse ente social é um ente de relaçóes de objetividade e de subjetividade que tem na linguagem sua forma de existência e através da qual estabelece relaçóes entre si. Esse processo é fenômeno psicossocial radicado na esfera pública (lugar de alteridade), pois fornece um terreno para seu cultivo e estabelecimento, e é "condição necessária para o desenvolvimento simbólico e para o desenvolvimento do Eu", como expóe a psicóloga social Sandra Jovchelovitch (2002, p. 65).

Para a filósofa e também psicóloga social Denise Jodelet, nas relaçóes com um mundo de objetos, de pessoas, de acontecimentos ou de ideias, o ente social náo representa apenas automatismo, nem está isolado num vazio social, pois partilha esse mundo com 
os outros, "às vezes de forma convergente, outras pelo conflito, para compreendê-lo, administrá-lo ou enfrentá-lo" na vida cotidiana. O contexto relacional representa uma forma de conhecimento socialmente elaborado e partilhado. Contribui para a construção de uma realidade comum a um conjunto social enquanto processo ao apropriar-se da realidade exterior ao pensamento, bem como elaborar psicológica e socialmente essa realidade a partir das relaçôes sociais (JODELET, 2001, p. 17).

A partir da resistência a uma ordem social estabelecida e excludente (status quo) reconhecer a existência do outro é ato concreto da negação ao reverter valores (transvaloração dos valores, como argumenta Nietzsche). Espacialmente, a experiência de resistência do ente social busca determinar sua existência enquanto sujeito no processo de transformação urbana, pois o ato de resistir é fenômeno de enunciação no ambiente hostil. $\mathrm{O}$ ato de resistir molda esse espaço urbano como um útero que gera e nutre experiências sociais no lugar - alteridade.

O relacionar-se com um outro caracteriza um direito de liberdade na alteridade: uma liberdade individual que configura a liberdade em sociedade, sendo desta forma autônoma, pois busca algo que se precisa livremente. Como define o sociólogo e filósofo Boaventura de Souza Santos (1997), a igualdade no direito à vida, no direito à cidade só desenvolverá seu potencial emancipatório na recusa de falsos universalismos para se tornar verdadeiramente multiculturais. Essas consideraçôes se pautam na possibilidade de um universalismo dos direitos em uma sociedade com traços culturais e sociais bem distintos. Ao observar e analisar qual, ou quais, são os direitos violados no cotidiano urbano, observa-se que há uma estrutura social e arranjo institucional que se define como "natural" e quer transmitir a ideia de que, em seu interior, as relaçōes humanas se desenvolvem entre iguais. Mas este "entre iguais" refere-se muitas vezes a uma condição socioeconômica. Um verniz de civilidade, de busca por desenvolvimento, de um ideário de progresso esconde ou submete uma estrutura social na qual o ente social é levado em conta na medida em que exerce a função de mero consumidor de produtos e bens, mas também de ideias e padróes de comportamento.

Os deserdados do direito de liberdade na alteridade que se desenvolve no espaço (direito à cidade) como obra em transformação e/ou os não reconhecidos são "os que melhor se adaptam à cidade porque sáo obrigados a tratar o espaço em torno de um modo selvagem que é necessário conhecer para sobreviver" (SANTOS, 2006). Então, pode-se afirmar que seu viver no espaço é um viver em estado de incertezas e promessas que conduz à sobrevivência como sintoma da não liberdade $\mathrm{O}$ ente social, ao participar ativamente dos rumos de sua vida, supera o estado de potência em ato. $\mathrm{O}$ ato do náo reconhecimento do outro como um ente social capaz de participar dos diálogos sobre os direitos à cidade conduz o processo de intervenção urbana na área central paulistana (que não é mera ilusão, mas baseia-se em efetivas relaçôes das coisas entre si), a tornar-se um simulacro - um espaço dessacralizado. Na determinaçáo da existência do ente social e constituiçáo da comunidade, as táticas de resistência do ente social prefiguram um sagrado selvagem ao representar uma determinaçáo contrária às estratégias do instituído, do status quo, num espaço urbano por ele controlado. Essas táticas são constituídas pela vigilância e observação de possíveis falhas em conjunturas particulares do poder instaurado por essa estratégia. A tática depende do tempo e deve 
jogar constantemente com os acontecimentos para transformá-los em ocasióes; é a possibilidade de o enfraquecido tirar partido de forças que lhe sáo estanhas e, muitas vezes, ocultas. Assim, defende-se uma negação da normatização excludente do espaço urbano (território marcado por disputas de poder) para que o ente social, através da alteridade, manifeste sua permanência e manutenção enquanto ente no espaço urbano.

\section{Referências}

ARANTES, Otília Beatriz Fiori. Uma estratégia fatal. A cultura nas novas gestôes urbanas. In: ARANTES, Otília Beatriz Fiori.; VAINER, Carlos B. e MARICATO, Ermínia. A cidade do pensamento único: desmanchando consensos. Petrópolis, Rio de Janeiro: Vozes, 2000 (Coleção Zero à Esquerda).

BASTIDE, Roger. O Sagrado Selvagem. E outros ensaios. Tradução Dorothée de Bruchard. São Paulo: Companhia das Letras, 2006.

BONDUKI, Nabil Georges. Origens da habitação social no Brasil. Arquitetura moderna, Lei do Inquilinato e difusão da casa própria. São Paulo: Estação Liberdade: FAPESP, 1998.

BRITO, Ênio José da Costa. A cultura popular e o Sagrado. In: QUEIROZ, José J. (Coord.). Interfaces do Sagrado. Em véspera de Milênio. Sáo Paulo: Olho d’Água/ Programa de Estudos Pós-Graduados em Ciências da Religiáo da PUC-SP, 1996, pp. 102-111. (Ciências da Religião 1).

ELIADE, Mircea. O sagrado e o profano: a essência das religiôes. Tradução: Rogério Fernandes. São Paulo: Martins Fontes, 2001.

FRÚGOLI JR, Heitor. Centralidade em São Paulo: Trajetórias, conflitos e negociaçôes na metrópole. São Paulo: Cortez, Editora da Universidade de São Paulo, 2000 .

JODELET, Denise. Representações Sociais: um domínio em expansão. In:

JODELET, Denise (Org.). As Representaçôes Sociais. Rio de Janeiro: Editora da UERJ, 2001.

JOVCHELOVITCH, Sandra. Vivendo a vida com os outros: intersubjetividade, espaço público e representaçóes sociais. In: GUARESCHI, Pedrinho A.;

JOVCHELOVITCH, Sandra. (Org.). Textos em representaçôes sociais. $7^{\mathrm{a}}$ ed., Petrópolis: Vozes, 2002.

KARA-JOSÉ, Beatriz. Políticas culturais e negócios urbanos: a instrumentalização da cultura na revalorização do centro de São Paulo (1975-2000). São Paulo: Annablume; FAPESP, 2007.

KOWARICK, Lúcio. A espoliação urbana. Rio de Janeiro: Paz e Terra, 1979.

KOWARICK, Lúcio. Áreas centrais de São Paulo: dinamismo econômico, pobreza e políticas. Lua Nova [online]. 2007, n.70, pp. 171-211. 
A busca por relações de alteridade como manifestação do sagrado...

LEFEBVRE, Henri. O direito à cidade. Tradução: Rubens Eduardo Frias. São Paulo: Moraes, 1991.

MARICATO, Ermínia e FERREIRA, João Sette Whitaker. Operação Urbana Consorciada: diversificação urbanística participativa ou aprofundamento da desigualdade? In: OSÓRIO, Letícia Marques. Estatuto da Cidade e Reforma Urbana: novas perspectivas para as cidades brasileiras. Porto Alegre/São Paulo: Sérgio Antônio Fabris Editor, 2002.

MELO, José Arnaldo Fonseca de. Cidade \& Saúde. (2014). Tese (Doutorado). São Paulo: Faculdade de Arquitetura e Urbanismo da Universidade de Sáo Paulo.

NOBRE, Eduardo Alberto Cusce. (2000). Reestruturação econômica e território: expansão recente do terciário na marginal do rio Pinheiros. Tese (doutorado). São Paulo: Faculdade de Arquitetura e Urbanismo da Universidade de São Paulo, 2000.

PEZOTI, Rosangela Helena. O Projeto Nova Luz e a participação dos sujeitos coletivos e políticos: um processo de reurbanização em questão. Tese (Doutorado em Serviço Social). Programa de Pós-Graduação em Serviço Social, Pontifícia Universidade Católica de São Paulo, PUC/SP, 2012. 228 p.

SANTOS, Boaventura de Sousa. Por uma concepção multicultural de direitos humanos. In: Revista Crítica de Ciências Sociais, no 48, jun. 1997. pp. 11-32.

SANTOS, Milton. A Natureza do Espaço: técnica e tempo, razão e emoçáo. 4a ed., 4a reimpr., São Paulo: Editora da Universidade de São Paulo, 2008. (Coleção Milton Santos, 1).

. O espaço do Cidadão. $7^{\text {a }}$ ed. Sáo Paulo: Editora da Universidade de São Paulo, 2007. (Coleção Milton Santos; 8).

Por uma Epistemologia Existencial. In: LEMOS, Amalia Inés Geraiges de; SILVEIRA, Maria Laura; ARROYO, Mônica. (org.) Questóes Territoriais na América Latina. Buenos Aires: Consejo Latinoamericano de Ciências Sociales CLACSO; São Paulo: Universidade de São Paulo, 2006. (Série Por uma Geografia Latino-Americana). pp. 19-26.

SIMÓES JR., José Geraldo. Revitalização de Centros Urbanos. São Paulo: Instituto Pólis, 1994. (Publicaçóes Pólis, 19).

SMITH, Neil. A gentrificação generalizada: de uma anomalia local à "regeneração" urbana como estratégia urbana global. In BIDOU-ZACHARIASEN, Catherine (org.). De volta à cidade: dos processos de gentrificação às políticas de "revitalização" dos centros urbanos. São Paulo: Annablume, 2006.

SOUZA, Marcelo José Lopes de. O território: sobre espaço e poder, autonomia e desenvolvimento. In: CASTRO, Iná Elias de. [et.al.] (org.). Geografia: conceitos e temas. Rio de Janeiro: Bertrand Brasil, 1995, pp. 77-116.

VARGAS, Heliana Comin e CASTILHO, Ana Luisa Howard de. Intervençóes em centros urbanos: objetivos, estratégias e resultados. São Paulo: Manole. 2006. 
VILLAÇA, Flávio. Espaço intra-urbano no Brasil. São Paulo: Studio Nobel: FAPESP: Lincoln Institute, 2001.

TUAN, YI-FU. Topofilia: um estudo da percepçáo, atitudes e valores do meio ambiente. Tradução: Lívia de Oliveira, 1980.

Recebido: 11 de fevereiro de 2019.

Aprovado: 11 de marçode 2019. 